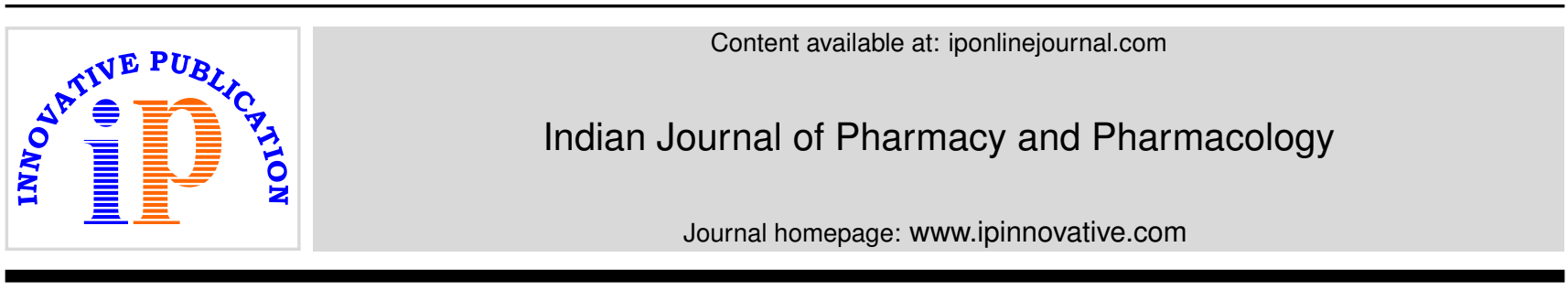

\title{
Editorial
}

\section{Overview of novel coronavirus in Punjab}

\author{
Amandeep Singh ${ }^{1} *$, Gurmeet Singh ${ }^{1}$, Raj Kumar Narang ${ }^{1}$, Uttam Kumar Mandal ${ }^{2}$ \\ ${ }^{1}$ Dept. of Pharmaceutics, ISF College of Pharmacy, Moga, Punjab, India \\ ${ }^{2}$ Dept. of Pharmaceutical Sciences and Technology, Maharaja Ranjit Singh Punjab Technical University, Bathinda, Punjab, India
}

\section{A R T I C L E I N F O}

Article history:

Received 06-04-2020

Accepted 27-04-2020

Available online 24-07-2020
(C) 2020 Published by Innovative Publication. This is an open access article under the CC BY-NC license (https://creativecommons.org/licenses/by-nc/4.0/)
From December 2019 Covid $-19^{1}$ has been spreading throughout the world wide, reached in Punjab ${ }^{2}$ by travelling of people from internationally to national site on 9 March 2020 as first positive report with initial symptoms. The effected patient has observed with high fever, cough, and difficulty breathing (severe cases) symptoms. ${ }^{2}$ The data has been obtained from the Covid -19 Punjab website. More than 12 districts have been affected by this novel corona virus represent by pie graph as Figure 2. Punjab government is doing many efforts to tackle with this condition.

\section{Methods for Prevention Suggested by W.H.O}

Frequently washing your hands with soap water or using alcohol-based sanitizer rub kills viruses that might be on your hands. Maintaining the social distancing with person who is coughing or sneezing. The minimum distance should be least 1 meter ( 3 feet), this will prevent the entrance of virus via small liquid droplets from their nose or mouth. Medial help id required if the persons feel fever, cough and difficulty breathing. Reduction in Un-necessary movement confirmed decreases the chances of contact with infected person. ${ }^{3}$ Staying at home is a best method to prevention. Do the five stop the spread of corona virus as shown in Figure 1.

\footnotetext{
* Corresponding author.

E-mail address: ad4singh@gmail.com (A. Singh).
}

\section{Specific Challenges}

At present, limited specific data are available on the clinical characteristics and natural course of critically ill patients with COVID-19. ${ }^{4}$ The limited number of ventilators are available in the hospital. ${ }^{5}$ If the numbers of patient is increased in upcoming days, then it's very difficult to provide the ventilators to each and every one. People are not following properly the rules given by W.H.O, it's necessary to obey the rules of W.H.O to control the covid-19.

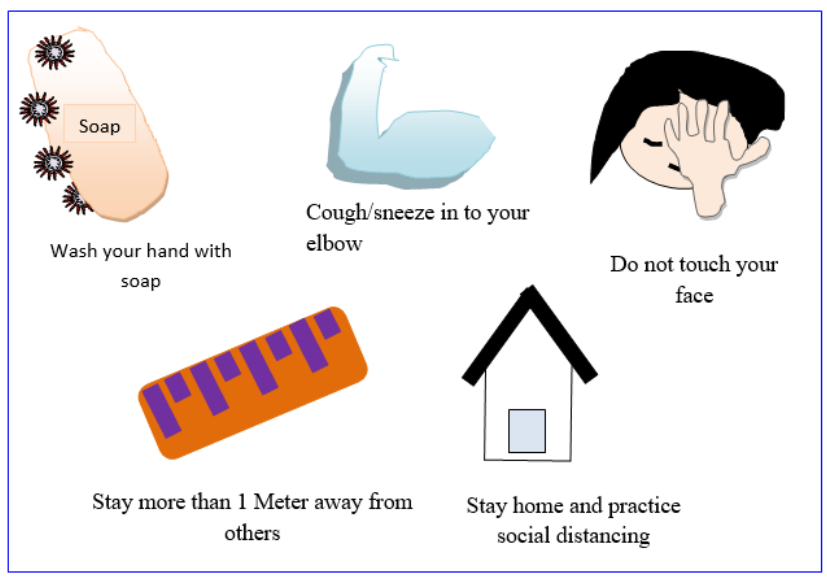

Fig. 1: Methods for prevention suggested by W.H.O 
Table 1: Ongoing vaccines against covid-19

\begin{tabular}{ll}
\hline Vaccines name & $\begin{array}{l}\text { Company/research group } \\
\text { (Ref-6) }\end{array}$ \\
Fusogenix DNA vaccine & Entos Pharmaceuticals \\
ChAdOx1 nCoV-19 & University of Oxford \\
Gimsilumab & Roivant Sciences \\
AdCOVID & Altimmune \\
TJM2 by I & Mab Biopharma \\
Coronavirus vaccine & Medicago \\
AT-100 (rhSP-D) & Airway Therapeutics \\
TZLS-501 & Tiziana Life Sciences \\
OYA1 & OyaGen \\
BPI-002 & Beyond Spring \\
Intranasal Covid-19 vaccine & Altimmune. \\
INO-4800 & Inovio Pharmaceuticals and \\
& Beijing Advaccine \\
NP-120 (Ifenprodil) & Biotechnology \\
APN01 & Algernon Pharmaceuticals \\
& University of British \\
Columbia and APEIRON \\
mRNA-1273 & Biologics \\
Avian Coronavirus & Moderna and Vaccine \\
Infectious Bronchitis Virus & Research Center \\
(IBV) & MIGAL Research Institute \\
TNX-1800 & \\
Brilacidin & Tonix Pharmaceuticals \\
Recombinant subunit & Innovation Pharmaceuticals \\
vaccine & Clover Biopharmaceuticals \\
Linear DNA Vaccine & DNA Sciences and Takis \\
BXT-25 & Biotech \\
INO-4700 (GLS-5300) & BIOXYTRAN \\
& Inovio in partnership with \\
Gene One Life Science. \\
\end{tabular}

Table 2: Ongoing research of drug against COVID-19

\begin{tabular}{ll} 
Drug & Company/research group(Ref-6) \\
Remdesivir (GS-5734) & Gilead Sciences \\
Actemra & Roche \\
Galidesivir & Biocryst Pharma's \\
SNG001 & Synairgen Research \\
Amnio Boost & Lattice Biologics \\
\hline
\end{tabular}

\section{Vaccine/Drugs in Pipeline for Covid -19}

The first COVID-19 vaccine in China is expected to be ready for clinical trials by the end of April. Health representative from WHO have noted that Gilead's remdesivir has shown effectiveness in treatment of corona virus infection. By US FDA is approved Chloroquine as emergency drug in corona virus infection. The US Food and Drug Administration (FDA) approved partial urgent situation utilize for chloroquine and hydroxychloroquine as a treatment for COVID-19 infection. In China Favilavir, the first approved drug for coronavirus. ${ }^{6}$

\section{Pharmaceutical Companies/Research Institutes Involved in Developing Coronavirus Drugs/Vaccines}

Various Pharmaceutical companies/research institutes are doing there effort to control the COVID-19. Here is a Table 1 and Table 2 of pharmaceutical companies across the world is developing drugs/vaccines against corona-virus.

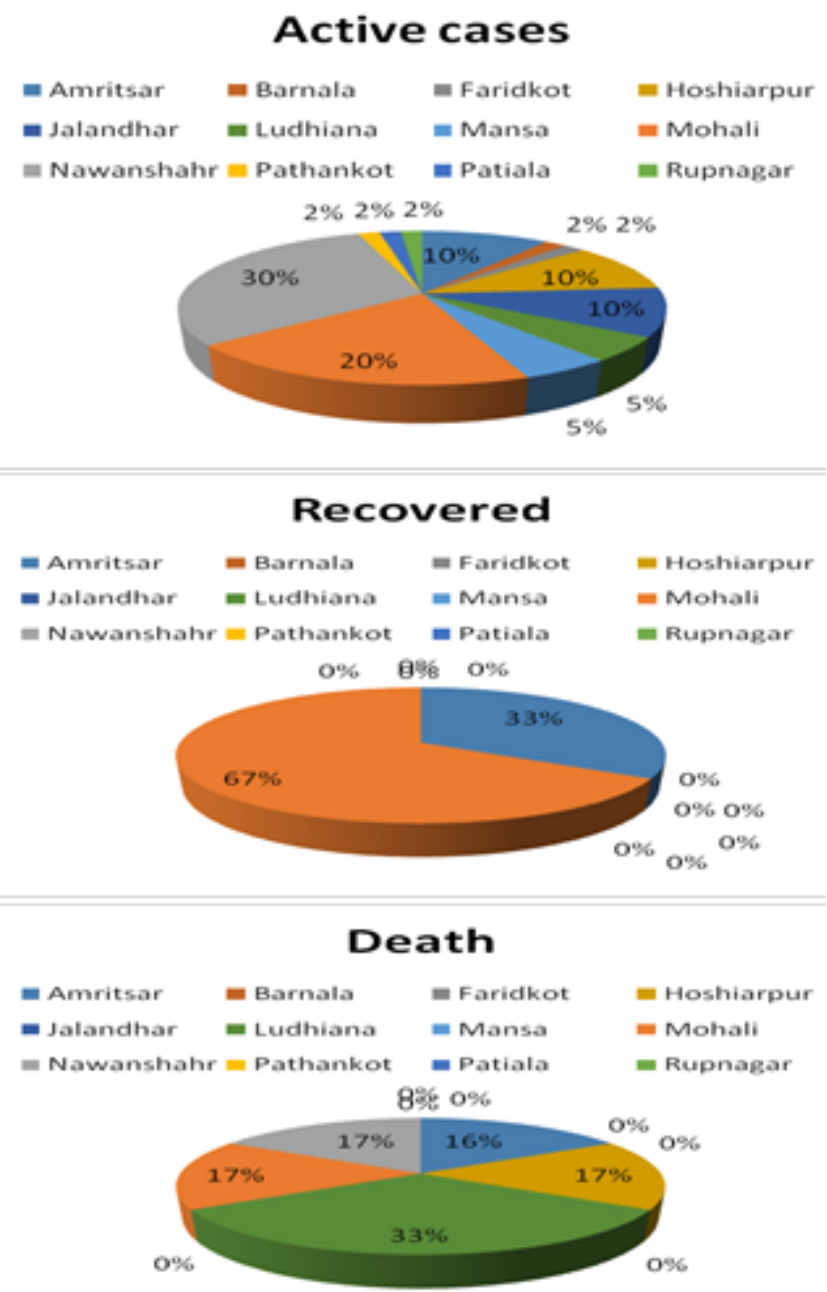

Fig. 2: Representation of corona virus effected active in Punjab from 9 December to 5 April data

\section{References}

1. Li Q, Guan X, Wu P, Wang X, Zhou L, Tong Y, et al. Early transmission dynamics in Wuhan, China, of novel coronavirus-infected pneumonia. New Engl J Med. 2020;

2. Livemint. Fresh coronavirus cases emerge from Punjab, Bengaluru; takes total to $45 ; 2020$.

3. Available from: https://www.who.int/emergencies/diseases/novelcoronavirus-2019/advice-for-public,

4. Arabi YM, Murthy S, Webb S. COVID-19: A novel coronavirus and a novel challenge for critical care. Intensive care medicine. 2020;p. 1-4.

5. Sharma A, Das M, Mishra B, Thakur A, Loomba PS. Ventilatorassociated events: Incidence and mortality in intensive care unit of 
a superspecialty hospital of North India. Int $J$ Health Allied Sci. 2020;9(1):62. doi:10.4103/1ihas.iphas_96_19.

6. Available from: https://WwW.clinicaltrialsarena.com/analysis/ coronavirus-mers-cov-drugs

\section{Author biography}

Amandeep Singh Assistant Professor

Gurmeet Singh Assistant Professor
Raj Kumar Narang Professor

Uttam Kumar Mandal Professor

Cite this article: Singh A, Singh G, Narang RK, Mandal UK. Overview of novel coronavirus in Punjab. Indian J Pharm Pharmacol 2020;7(2):54-56 